Audiology

Neurotology
Audiol Neurotol 2010;15:383-393

DOI: $\underline{10.1159 / 000307345}$
Received: October 12,2009

Accepted: February 5, 2010

Published online: April 10, 2010

\title{
A Histological Study of Scala Communis with Radiological Implications
}

\author{
Chadi Makary Jennifer Shin Paul Caruso Hugh Curtin Saumil Merchant \\ Massachusetts Eye and Ear Infirmary and Harvard Medical School, Boston, Mass., USA
}

\section{Key Words}

Cochlea $\cdot$ Inner ear anomalies $\cdot$ Mondini defect .

Scala communis $\cdot$ Mesoderm

\begin{abstract}
Objectives: Scala communis or interscalar septum (IS) defect is a developmental abnormality of the inner ear characterized by a dehiscence in the partition separating the turns of the cochlea. The goals of the present study were to (1) study this anomaly and describe its characteristics compared to control ears using a histological analysis of temporal bones, (2) discuss radiological implications regarding its diagnosis, and (3) describe its embryological derivation. Methods: Out of 1775 temporal bones assessed, 22 specimens were found to have scala communis in cochleae containing all 3 turns (basal, middle and apical). These 22 ears were studied in detail by qualitative and quantitative methods using light microscopy. Results: Scala communis occurred as an isolated inner ear anomaly, or in association with other congenital cochlear and/or vestibular anomalies. The defect occurred most often between the middle and apical turns of the cochlea. Compared to control ears, scala communis ears were found to have a smaller modiolar area $(p<0.0001)$ and flattening of the interscalar ridge (point of attachment of the IS to the inner lumen of the cochlea; $p<0.0001$ ). Scala communis was compatible with normal hearing. Conclusions: Flattening of the interscalar ridge has the potential to improve
\end{abstract}

the diagnosis of scala communis in patients using CT scanning. The anomaly may result from a mesodermal defect such as excessive resorption of mesenchyme during the formation of the scalae, an error in the formation of bone, or both.

Copyright $\odot 2010$ S. Karger AG, Basel

\section{Introduction}

Scala communis is a defect in the bony interscalar septum (IS) separating the turns of the cochlea. The earliest depiction of this anomaly was made in 1791 when Carlo Mondini [1791] described a short cochlea with 1.5 turns and an incomplete IS associated with an enlarged vestibular aqueduct. Since then, the anomaly has been described in many histological studies, and termed 'scala communis' [Alexander, 1904; Schuknecht, 1974, 1993], 'cloaca' [Nager, 1907] and 'IS defect' [Altmann, 1953]. Scala communis can occur as part of a broader inner ear abnormality such as the Mondini defect [Mondini, 1791; Schuknecht, 1974, 1980, 1993; Paparella, 1980; Zheng et al., 2002], or as an isolated cochlear anomaly [Guild, 1929; Schuknecht, 1993]. Scala communis is a common developmental anomaly of the inner ear. Schuknecht [1974] reported an incidence of scala communis of $2 \%$ in a study of 375 bones.

\section{KARGER}

() 2010 S. Karger AG, Basel

Fax +41613061234 E-Mail karger@karger.ch www.karger.com www.karger.com/aud
Chadi Makary, MD

Department of Otolaryngology, Massachusetts Eye and Ear Infirmary 243 Charles Street

Boston, MA 02114 (USA)

Tel. +1 617573 3712, Fax +1 617573 3939, E-Mail Chadi_Makary@ meei.harvard.edu 
Fig. 1. a Normal right cochlea. The bony IS (IS1, IS2 and IS3) is complete. The interscalar ridges 2 and 3 are shown. b Right cochlea with scala communis. The septum is defective in IS2 and IS3 (black arrows). Interscalar ridges 2 and 3 are flattened. $\mathrm{LB}=$ Lower basal turn; UB = upper basal turn; $\mathrm{LM}=$ lower middle turn; $\mathrm{UM}=$ upper middle turn; Ap = apical turn.
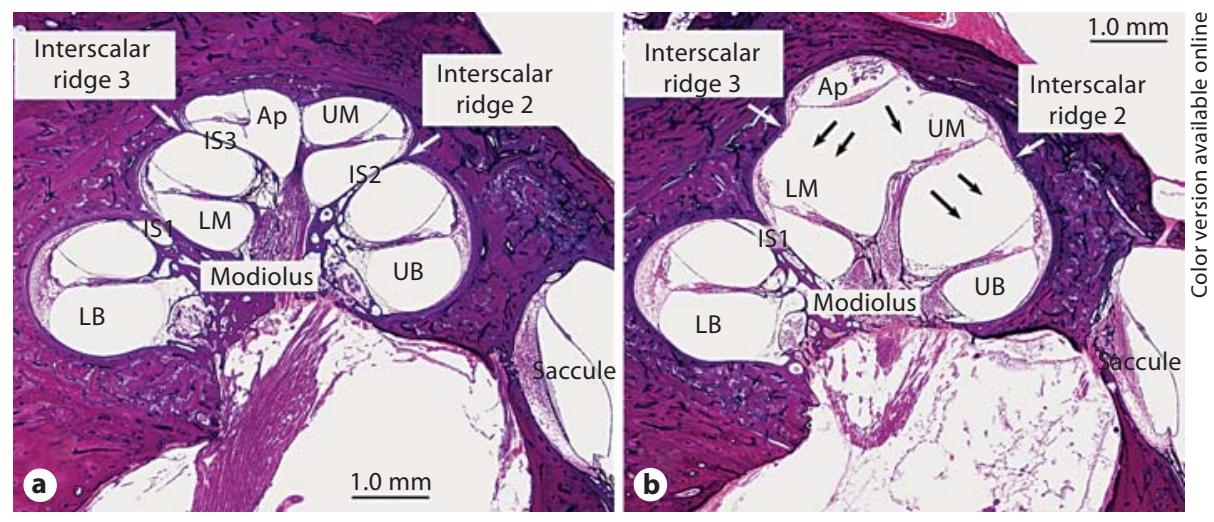

Radiologists also recognize this abnormality as a common inner ear defect, often in association with an enlarged vestibular aqueduct [Jackler et al., 1987; Jardin and Vignaud, 1988; Phelps, 1990; Sennaroglu and Saatçi, 2002, 2004; Romo et al., 2003]. The terms 'incomplete partition of the cochlea' [Jackler et al., 1987; Sennaroglu and Saatçi, 2002, 2004], 'défaut de segmentation' (segmentation defect) [Jardin and Vignaud, 1988], Mondini and pseudo-Mondini defects [Phelps, 1990], and undersegmentation of the cochlea are used by radiologists to describe an IS defect.

One can differentiate between scala communis occurring in a cochlea with all 3 turns (basal, middle and apical) and that occurring in a shortened cochlea (2 turns or less). The present study focused only on scala communis occurring in cochleae with all 3 turns. We made qualitative and quantitative observations of the inner ear morphology in our temporal bone specimens. These observations were compared to age- and sex-matched controls. We also discuss the embryological basis for this malformation and the radiological implications of our observations.

\section{Material and Methods}

Our specimens came from the temporal bone collection at the Massachusetts Eye and Ear Infirmary. These specimens were removed at autopsy and processed for light microscopy according to the method described by Schuknecht [1993]. Briefly, the bones were fixed with $10 \%$ neutral buffered formalin, decalcified using trichloroacetic acid or ethylenediaminetetraacetate, embedded in celloidin, sectioned in the axial or vertical plane at $20 \mu \mathrm{m}$ thickness, and every 10th section was stained with hematoxylin and eosin. All axially-sectioned bones were screened for bony inner ear anomalies including anomalies of the cochlea, vestibule and semicircular canals. Cochleae with scala communis were divided into 2 groups: those with more than 2 cochlear turns, and those with 2 or less turns (short cochleae).
Only those bones with both scala communis and all 3 turns (basal, middle and apical) were studied in more detail. Figure 1a shows a midmodiolar section of a normal right cochlea with basal, middle and apical turns. To facilitate our study, we divided the IS into 3 parts as seen on a midmodiolar section. IS1 is the most proximal part, separating the lower basal turn from the lower middle turn. IS2 is more distal, separating the upper basal from the upper middle turn; IS2 attaches to the outer wall of the cochlea at the second interscalar ridge (R2). IS3 is the most distal part of the septum, separating the lower middle turn from the apical turn, and it attaches to the cochlear lumen at the third interscalar ridge (R3). The IS is thick proximally and thins out distally until it is absent at the helicotrema between the upper middle and apical turns. Figure $1 \mathrm{~b}$ shows a midmodiolar section of a right cochlea with scala communis. The basal, middle and apical turns are present. However, the IS is defective, and its distal part (IS2 and IS3) is absent.

Qualitative assessments were made on each bone with scala communis, including the side of ear, age and sex, location of scala communis, presence or absence of the scala media and organ of Corti in each turn, presence or absence of dendritic fibers in the osseous spiral lamina in each turn, size of vestibular aqueduct, and any associated bony vestibular anomalies. Audiometric data, if available, were reviewed. Quantitative measurements (fig. 2) were made using 3 sections from each bone: the midmodiolar section plus 1 section above and 1 below. The measurements included the cochlear area, modiolar area, angles of the R2 and R3, and 2 distances $\mathrm{AB}$ and $\mathrm{AC}$ (defined below). These same qualitative and quantitative assessments were also made on a group of ageand sex-matched bones that served as controls. The cochlear and modiolar areas were obtained by drawing a line along the edge of the cochlear lumen and modiolus, respectively (fig. $2 \mathrm{a}, \mathrm{d}$ ). The angle of each interscalar ridge was defined by drawing 2 tangents going from the point of attachment of the IS, 1 to the turn below, and 1 to the turn above. The acute angle obtained by the 2 tangents was then measured (fig. $2 b$, e). In order to obtain the distances $\mathrm{AB}$ and $\mathrm{AC}, 2$ tangents $\mathrm{T} 1$ and $\mathrm{T} 2$ were first drawn (fig. $2 \mathrm{c}$, f). T1 connected the upper basal and upper middle cochlear turns, whereas T2 connected the lower basal and upper basal turns. Point A is the point of attachment of the IS2 to R2. Point B is the point of intersection of a perpendicular line drawn from point $A$ to tangent T1. Point $\mathrm{C}$ is the point of intersection of a perpendicular line from point A to tangent T2. Measurements were made using ImageJ version 1.32 software. 

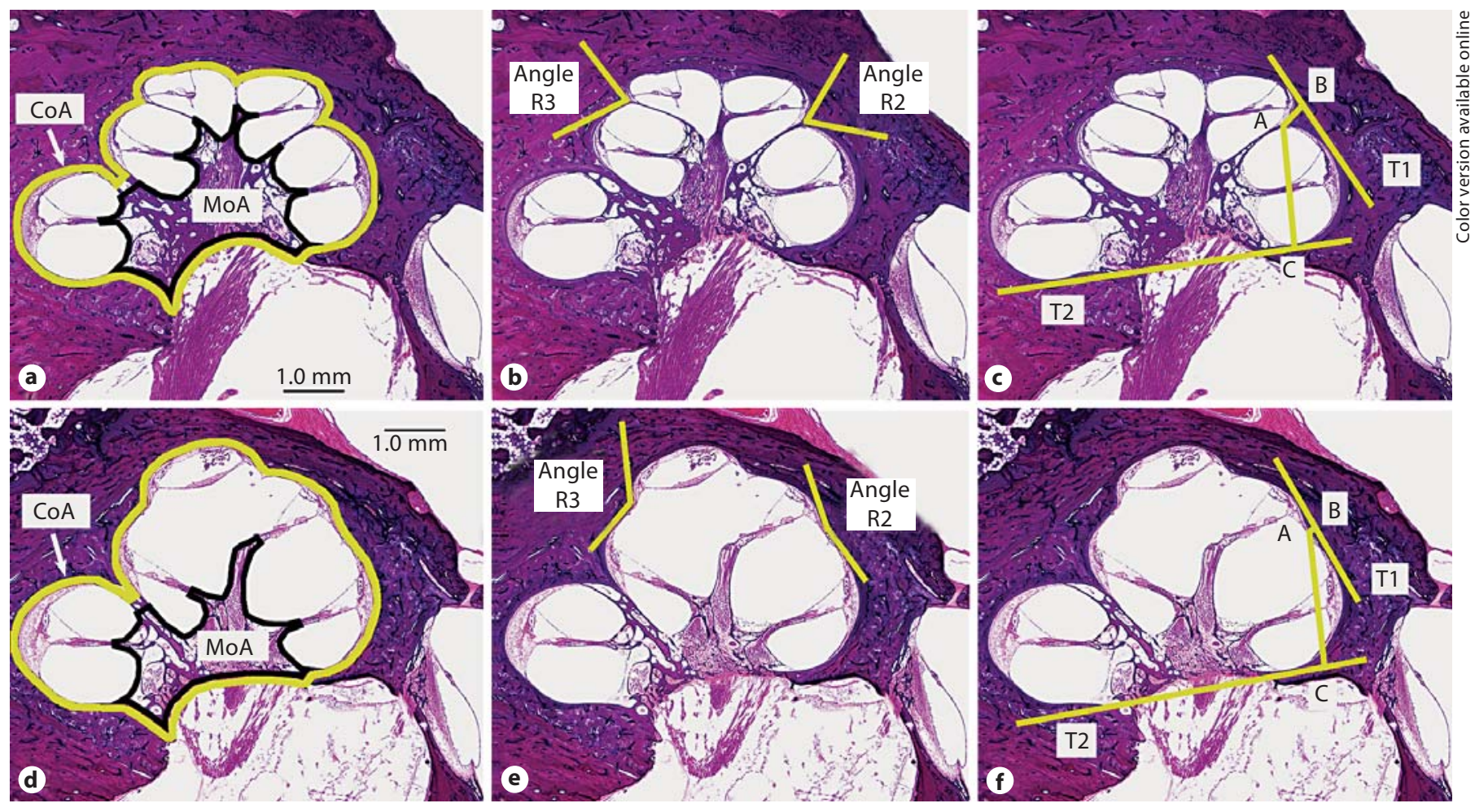

Fig. 2. Measurements made on control and scala communis ears. a, $\mathbf{d}$ Cochlear area (CoA; yellow line) and modiolar area (MoA; black line). b, e Angles of interscalar ridges R2 and R3 (yellow lines). c, f Distances AB and AC (yellow lines). T1: tangent to upper basal and upper middle turns. T2: tangent to lower basal and upper basal turns. $\mathrm{AB}$ is perpendicular to $\mathrm{T} 1$, and $\mathrm{AC}$ is perpendicular to $\mathrm{T} 2$.

Two dimensional graphic reconstructions of the cochlear ducts and spiral ganglia were performed according to the method described by Guild et al. [1931] and Schuknecht [1953]. The lengths of the cochlear duct and Rosenthal canal were measured. The number of spiral ganglion cells was counted and compared to age-matched normal controls established by Otte et al. [1978].

Statistical calculations to compare the measurements in scala communis ears versus controls were performed using Stata version 10 (StataCorp LP, College Station, Tex., USA). Hypothesis testing was performed utilizing the independent two-sample Student $t$ test with unequal variances. Receiver operating characteristic (ROC) analysis allowed for a nonparametric calculation of the area under the ROC curve, as well as of sensitivity, specificity and accuracy at progressive threshold values.

\section{Results}

A total of 1900 temporal bones were reviewed. We excluded specimens when the inner ear could not be assessed (e.g. destruction by malignancy, labyrinthitis ossificans, removal artifact, etc.), and those sectioned in the vertical plane. We assessed 1775 axially sectioned bones,
Table 1. Incidence of bony inner ear anomalies

\begin{tabular}{lrl}
\hline & $\begin{array}{l}\text { Number } \\
\text { of bones }\end{array}$ & $\begin{array}{l}\text { Percentage } \\
\text { of total }\end{array}$ \\
\hline Cochlear anomalies ( \pm vestibular anomalies) & 74 & 4 \\
Scala communis in cochleae with all 3 turns & 22 & 1.2 \\
Scala communis in cochleae with $\leq 2$ turns & 20 & 1 \\
Isolated vestibular anomalies & 6 & 0.3 \\
Total bony anomalies & 80 & 4.5 \\
\hline Total & 1775 \\
\hline
\end{tabular}

of which 80 had bony inner ear anomalies, for an incidence of $4.5 \%$. Of these 80 bones, 74 (4\%) had cochlear anomalies ( \pm vestibular anomalies), while 6 had isolated vestibular anomalies. Of the 74 bones with cochlear anomalies, 42 (2.4\%) had scala communis, including 22 specimens with cochleae containing all 3 turns, and 20 ears with shortened cochleae ( $\leq 2$ turns). Table 1 summarizes these findings. 
Table 2. Qualitative assessments

a Ears with scala communis

\begin{tabular}{|c|c|c|c|c|c|c|c|c|c|c|c|c|}
\hline $\begin{array}{l}\text { Case } \\
\text { No. }\end{array}$ & $\begin{array}{l}\text { Ear/ } \\
\text { side } \\
\text { No./- }\end{array}$ & $\begin{array}{l}\text { Age/sex } \\
\text { years/- }\end{array}$ & $\begin{array}{l}\text { Coch- } \\
\text { lear } \\
\text { turns, } n\end{array}$ & $\begin{array}{l}\text { Location } \\
\text { of scala } \\
\text { communis }\end{array}$ & $\begin{array}{l}\text { Scala } \\
\text { media }\end{array}$ & Organ of Corti & $\begin{array}{l}\text { Dendritic fibers in } \\
\text { osseous spiral lamina }\end{array}$ & $\begin{array}{l}\text { Bony } \\
\text { vestibule }\end{array}$ & $\begin{array}{l}\text { Bony } \\
\text { SCC }\end{array}$ & $\begin{array}{l}\text { Size of } \\
\text { vestibular } \\
\text { aqueduct }\end{array}$ & Audiogram & Otologic diagnosis \\
\hline 1 & $1 / \mathrm{L}$ & $0.25 / \mathrm{M}$ & 2.5 & IS 2,3 & Co & present in all turns & present in all turns & enlarged & normal & normal & not available & trisomy $13-15$ \\
\hline 2 & $2 / \mathrm{L}$ & $0.3 / \mathrm{M}$ & 2.5 & IS 2,3 & Co & present in all turns & absent $^{1}$ & normal & $\begin{array}{l}\text { wide lat- } \\
\text { eral SCC }\end{array}$ & normal & not available & trisomy 18 \\
\hline 3 & $3 / \mathrm{L}$ & $13 / \mathrm{M}$ & 2.5 & IS2, 3 & Co & present in all turns & present in all turns & normal & normal & normal & not available & normal \\
\hline 4 & $4 / \mathrm{R}$ & $18 / \mathrm{M}$ & 2.75 & IS3 & Co & present in all turns & present in all turns & normal & normal & normal & normal hearing & normal \\
\hline 4 & $5 / \mathrm{L}$ & $18 / \mathrm{M}$ & 2.75 & IS 2,3 & Co & present in all turns & present in all turns & normal & normal & normal & SNHL & craniopharyngioma \\
\hline 5 & $6 / \mathrm{R}$ & $33 / \mathrm{F}$ & 2.5 & IS3 & Co & present in all turns & present in all turns & normal & normal & normal & normal hearing & normal \\
\hline 6 & $7 / \mathrm{R}$ & $41 / \mathrm{F}$ & 3 & IS2, 3 & Co & present in all turns & present in all turns & normal & normal & normal & normal hearing & normal \\
\hline 6 & $8 / \mathrm{L}$ & $41 / \mathrm{F}$ & 2.75 & IS3 & Co & present in all turns & present in all turns & normal & normal & normal & normal hearing & normal \\
\hline 7 & $9 / \mathrm{R}$ & $55 / \mathrm{M}$ & 2.5 & IS3 & Co & present in all turns & present in all turns & normal & normal & normal & $\begin{array}{l}\text { high frequency } \\
\text { SNHL }\end{array}$ & Fabry's disease \\
\hline 8 & $10 / \mathrm{R}$ & $56 / \mathrm{M}$ & 2.5 & IS3 & Co & atrophic ${ }^{2}$ & present in all turns & normal & normal & normal & SNHL & $\begin{array}{l}\text { measles } \\
\text { labyrinthitis }\end{array}$ \\
\hline 8 & $11 / \mathrm{L}$ & $56 / \mathrm{M}$ & 2.5 & IS 2,3 & Co & atrophic $^{2}$ & present in all turns & normal & normal & normal & SNHL & $\begin{array}{l}\text { measles } \\
\text { labyrinthitis }\end{array}$ \\
\hline 9 & $12 / \mathrm{R}$ & $58 / \mathrm{M}$ & 2.75 & IS3 & Co & present in all turns & present in all turns & normal & normal & normal & not available & normal \\
\hline 10 & $13 / \mathrm{L}$ & $63 / \mathrm{F}$ & 2.25 & IS 2,3 & Co & present in all turns & present in all turns & normal & normal & normal & flat SNHL & presbycusis \\
\hline 11 & $14 / \mathrm{R}$ & $65 / F$ & 2.5 & IS2, 3 & Co & atrophic $^{2}$ & present in all turns & normal & $\begin{array}{l}\text { all } 3 \text { canals } \\
\text { short }\end{array}$ & enlarged & flat SNHL & Mondini dysplasia \\
\hline 11 & $15 / \mathrm{L}$ & $65 / \mathrm{F}$ & 2.5 & IS1, 2, 3 & Co & atrophic ${ }^{2}$ & present in all turns & normal & $\begin{array}{l}\text { all } 3 \text { canals } \\
\text { short }\end{array}$ & enlarged & flat SNHL & Mondini dysplasia \\
\hline 12 & $16 / \mathrm{R}$ & $65 / \mathrm{M}$ & 2.5 & IS3 & Co & atrophic $^{2}$ & present in all turns & normal & normal & normal & SNHL & Usher's syndrome \\
\hline 13 & $17 / \mathrm{R}$ & $69 / \mathrm{M}$ & 2.5 & IS3 & Co & present in all turns & present in all turns & normal & $\begin{array}{l}\text { post. SCC } \\
\text { dysplasia }\end{array}$ & normal & SNHL & $\begin{array}{l}\text { endolymphatic } \\
\text { hydrops }\end{array}$ \\
\hline 13 & $18 / \mathrm{L}$ & $69 / \mathrm{M}$ & 2.5 & IS3 & Co & present in all turns & present in all turns & normal & normal & normal & mixed HL & osteoradionecrosis \\
\hline 14 & $19 / \mathrm{R}$ & $77 / \mathrm{F}$ & 2.75 & IS 2,3 & Co & present in all turns & present in all turns & normal & normal & normal & $\begin{array}{l}\text { high frequency } \\
\text { SNHL }\end{array}$ & unknown \\
\hline 15 & $20 / \mathrm{R}$ & $83 / \mathrm{M}$ & 2.5 & IS3 & Co & present in all turns & present in all turns & normal & normal & normal & flat SNHL & presbycusis \\
\hline$\overline{15}$ & $21 / \mathrm{L}$ & $83 / \mathrm{M}$ & 2.5 & IS3 & Co & present in all turns & present in all turns & normal & normal & normal & flat SNHL & presbycusis \\
\hline 16 & $22 / \mathrm{L}$ & $86 / \mathrm{F}$ & 2.5 & IS3 & Co & atrophic $^{2}$ & present in all turns & normal & normal & normal & SNHL & DFNA9 \\
\hline
\end{tabular}

The rest of the qualitative and quantitative studies were focused on those 22 bones with scala communis in cochleae with all 3 turns. Table 2 a shows the qualitative data on these 22 cases. The age ranged from newborn to 86 years, $55 \%$ of the cases were bilateral, and $64 \%$ were male. The scala media was formed and the organ of Corti was developed in all turns of all ears. However, the organ of Corti was atrophic in 6 ears due to various pathologies (measles labyrinthitis, Usher's syndrome, DFNA9, etc.). Dendritic fibers were seen in osseous spiral lamina in all turns of all ears except ear No. 2 (which had severe hypoplasia of the cochlear nerve). IS1 was defective in only 1 ear; IS2 was defective in 10 ears, while IS3 was defective in all 22 ears. In the single case where IS1 was defective, IS2 and IS3 were also absent. Associated bony vestibular anomalies included an enlarged vestibule (1 ear), enlarged lateral semicircular canal (1 ear), bilateral short semicircular canals and an enlarged vestibular aqueduct ( 2 ears), and a dysplastic posterior semicircular canal (1 ear). Notably, normal hearing was reported on audiometric testing in 4 cases. Many cases showed sensorineural or mixed hearing loss attributable to other diagnoses (e.g. craniopharyngioma invading the internal auditory canal, Usher's syndrome, measles labyrinthitis, presbycusis, Fabry's disease, DFNA9, etc.). Table $2 \mathrm{~b}$ shows the qualitative data on the control ears.

Table 3 and figure 3 show the results of the quantitative measurements for both scala communis and control ears. Compared to the controls, the scala communis ears had significantly larger R2 angles (mean of 110 vs. $59^{\circ}$; $\mathrm{p}<0.0001$ ) and R3 angles (mean of $115 \mathrm{vs.} 56^{\circ} ; \mathrm{p}<0.0001$ ). The modiolar area was significantly smaller in ears with scala communis (mean of 3.02 vs. $3.93 \mathrm{~mm}^{2}$; p < 0.0001). However, the cochlear area was similar (mean of 13.64 


\begin{tabular}{|c|c|c|c|c|c|c|c|c|c|c|c|}
\hline $\begin{array}{l}\text { Case } \\
\text { No. }\end{array}$ & $\begin{array}{l}\text { Ear/ } \\
\text { side } \\
\text { No./- }\end{array}$ & $\begin{array}{l}\text { Age/sex } \\
\text { years/- }\end{array}$ & $\begin{array}{l}\text { Coch- } \\
\text { lear } \\
\text { turns, n }\end{array}$ & $\begin{array}{l}\text { Scala } \\
\text { media }\end{array}$ & Organ of Corti & $\begin{array}{l}\text { Dendritic fibers in } \\
\text { osseous spiral lamina }\end{array}$ & $\begin{array}{l}\text { Bony } \\
\text { vestibule }\end{array}$ & $\begin{array}{l}\text { Bony } \\
\text { SCC }\end{array}$ & $\begin{array}{l}\text { Size of } \\
\text { vestibular } \\
\text { aqueduct }\end{array}$ & Audiogram & Otologic diagnosis \\
\hline 1 & $1 / \mathrm{L}$ & $0.2 / \mathrm{M}$ & 2.5 & Co & present in all turns & present in all turns & normal & normal & normal & not available & normal \\
\hline 2 & $2 / \mathrm{L}$ & $0.2 / \mathrm{M}$ & 2.5 & Co & present in all turns & present in all turns & normal & normal & normal & not available & normal \\
\hline 3 & $3 / \mathrm{L}$ & $12 / \mathrm{M}$ & 2.5 & Co & present in all turns & present in all turns & normal & normal & normal & not available & normal \\
\hline 4 & $4 / \mathrm{L}$ & $15 / \mathrm{M}$ & 2.5 & Co & atrophic $^{2}$ & present in all turns & normal & normal & normal & SNHL & Alport syndrome \\
\hline 5 & $5 / \mathrm{R}$ & $17 / \mathrm{M}$ & 2.5 & Co & present in all turns & present in all turns & normal & normal & normal & not available & normal \\
\hline 6 & $6 / \mathrm{R}$ & $32 / \mathrm{F}$ & 2.5 & Co & present in all turns & present in all turns & normal & normal & normal & CHL & chronic otitis media \\
\hline 7 & $7 / \mathrm{L}$ & $41 / \mathrm{F}$ & 2.5 & Co & present in all turns & present in all turns & normal & normal & normal & not available & normal \\
\hline 8 & $8 / \mathrm{R}$ & $43 / \mathrm{F}$ & 2.5 & Co & present in all turns & present in all turns & normal & normal & normal & SNHL & neurofibromatosis type 2 \\
\hline 9 & $9 / \mathrm{R}$ & $55 / \mathrm{M}$ & 2.5 & Co & present in all turns & present in all turns & normal & normal & normal & normal hearing & trisomy 21 \\
\hline 10 & $10 / \mathrm{L}$ & $56 / \mathrm{M}$ & 2.5 & Co & present in all turns & present in all turns & normal & normal & normal & not available & normal \\
\hline 11 & $11 / \mathrm{R}$ & $57 / \mathrm{M}$ & 2.5 & Co & present in all turns & present in all turns & normal & normal & normal & not available & trisomy 21 \\
\hline 12 & $12 / \mathrm{R}$ & $57 / \mathrm{M}$ & 2.5 & Co & present in all turns & present in all turns & normal & normal & normal & not available & tuberculosis otitis media \\
\hline 13 & $13 / \mathrm{L}$ & $61 / \mathrm{F}$ & 2.5 & Co & present in all turns & present in all turns & normal & normal & normal & flat SNHL & salicylate ototoxicity \\
\hline 14 & $14 / \mathrm{L}$ & $61 / \mathrm{F}$ & 2.5 & Co & present in all turns & present in all turns & normal & normal & normal & not available & normal \\
\hline 15 & $15 / \mathrm{R}$ & $64 / \mathrm{F}$ & 2.5 & Co & present in all turns & present in all turns & normal & normal & normal & mixed HL & presbycusis, tympanosclerosis \\
\hline 16 & $16 / \mathrm{R}$ & $65 / \mathrm{M}$ & 2.5 & Co & present in all turns & present in all turns & normal & normal & normal & mixed HL & otosclerosis, congenital SNHL \\
\hline 17 & $17 / \mathrm{R}$ & $69 / \mathrm{M}$ & 2.5 & Co & present in all turns & present in all turns & normal & normal & normal & not available & chronic petrositis \\
\hline 18 & $18 / \mathrm{L}$ & $71 / \mathrm{M}$ & 2.5 & Co & present in all turns & present in all turns & normal & normal & normal & not available & herpes zoster oticus \\
\hline 19 & $19 / \mathrm{R}$ & $74 / \mathrm{F}$ & 2.5 & Co & present in all turns & present in all turns & normal & normal & normal & high frequency SNHL & presbycusis \\
\hline 20 & $20 / \mathrm{L}$ & $81 / \mathrm{M}$ & 2.5 & Co & present in all turns & present in all turns & normal & normal & normal & high frequency SNHL & presbycusis \\
\hline 21 & $21 / \mathrm{R}$ & $82 / \mathrm{M}$ & 2.75 & Co & present in all turns & present in all turns & normal & normal & normal & not available & presbycusis \\
\hline 22 & $22 / \mathrm{R}$ & $85 / \mathrm{F}$ & 2.5 & Co & present in all turns & present in all turns & normal & normal & normal & not available & normal \\
\hline
\end{tabular}

SCC = Semicircular canal(s); R = right $\mathrm{L}=$ left; $\mathrm{M}=$ male; $\mathrm{F}=$ female; $\mathrm{IS}=$ interscalar septum; $\mathrm{Co}=$ complete; $\mathrm{SNHL}=$ sensorineural hearing loss; $\mathrm{CHL}=$ conductive hearing loss.

${ }^{1}$ Fibers were present only in hook region. ${ }^{2}$ Present in all 3 turns but atrophic.

$\mathrm{mm}^{2}$ in scala communis vs. $14.41 \mathrm{~mm}^{2}$ in controls; $\mathrm{p}=$ 0.07). The calculated ratio of modiolar:cochlear area was significantly smaller in scala communis ears (mean of 0.22 vs. $0.27 ; \mathrm{p}<0.0001$ ). The scala communis ears also had a significantly smaller $\mathrm{AB}$ distance (mean of $0.25 \mathrm{vs.}$ $0.37 \mathrm{~mm} ; \mathrm{p}=0.0002)$, but there was no difference in the AC distance (mean of 2.06 vs. $2.06 \mathrm{~mm}$; $\mathrm{p}=0.95$ ).

Table 4 shows the results for graphic reconstructions of the cochlear duct and spiral ganglion. Two ears (No. 1 and 2 with diagnoses of trisomy 13-15 and 18, respectively) had short cochlear ducts, measuring 24.9 and 23.5 $\mathrm{mm}$, respectively. The remaining 20 ears had a mean length of the cochlear duct of $30.3 \mathrm{~mm}$ (range: 27.3-36.2 $\mathrm{mm}$ ), which is similar to that seen in normal ears [Schuknecht, 1993]. Spiral ganglion reconstructions were not performed on ears with measles labyrinthitis, DFNA9, Usher's syndrome, osteoradionecrosis and craniopharyngioma because these confounding pathologies had caused a degeneration of spiral ganglion cells. In addition, ear No. 7 was excluded because of an artifact. One ear (No. 2) had only 441 cells (1\% of mean count in controls), and these were located in a severely shortened Rosenthal canal measuring only $1.4 \mathrm{~mm}$ in the basal turn. Another ear (No. 1) had 27711 cells ( $78 \%$ of mean count in controls); however, Rosenthal's canal in this ear was severely hypoplastic and most of the cells were located within the internal auditory canal. In the remaining 13 ears, Rosenthal's canal consisted of the normal 1.5 turns and its length ranged from 12 to $16.5 \mathrm{~mm}$, which is similar to normal ears [Otte et al., 1978].

Angles R2 and R3, the modiolar area and distance AB were then studied as possible diagnostic tests to detect scala communis (using CT scans on patients). For this purpose, we qualitatively reviewed all 74 bones with all types of cochlear anomalies. Flattening of the R2 and R3 (large angles) was always associated with a corresponding absent IS. However, modiolar hypoplasia was seen in scala communis, and as a separate anomaly as well as in association with other cochlear anomalies (without scala communis). The ROC analysis indicated that the angle 
Table 3. Quantitative measurements

a Ears with scala communis

\begin{tabular}{|c|c|c|c|c|c|c|c|}
\hline $\begin{array}{l}\text { Ear } \\
\text { No. }\end{array}$ & $\begin{array}{l}\text { Angle R2 } \\
\text { degrees }\end{array}$ & $\begin{array}{l}\text { Angle R3 } \\
\text { degrees }\end{array}$ & $\begin{array}{l}\mathrm{CoA} \\
\mathrm{mm}^{2}\end{array}$ & $\begin{array}{l}\text { MoA } \\
\mathrm{mm}^{2}\end{array}$ & $\mathrm{MoA} / \mathrm{CoA}$ & $\begin{array}{l}\mathrm{AC} \\
\mathrm{mm}\end{array}$ & $\begin{array}{l}\mathrm{AB} \\
\mathrm{mm}\end{array}$ \\
\hline 1 & 135 & 158 & 10.16 & 1.31 & 0.13 & 1.74 & 0.20 \\
\hline 2 & 105 & 126 & 11.18 & 2.19 & 0.20 & 1.87 & 0.17 \\
\hline 3 & 97 & 136 & 15.30 & 2.81 & 0.18 & 2.14 & 0.35 \\
\hline 4 & 114 & 111 & 14.71 & 3.14 & 0.21 & 2.01 & 0.26 \\
\hline 5 & 110 & 116 & 14.60 & 3.27 & 0.22 & 2.01 & 0.29 \\
\hline 6 & 76 & 87 & 13.91 & 3.62 & 0.26 & 1.95 & 0.31 \\
\hline 7 & 125 & 88 & 14.25 & 2.89 & 0.20 & 1.99 & 0.17 \\
\hline 8 & 123 & 107 & 13.10 & 2.53 & 0.19 & 1.93 & 0.19 \\
\hline 9 & 79 & 88 & 14.67 & 3.65 & 0.25 & 2.22 & 0.30 \\
\hline 10 & 153 & 110 & 13.68 & 3.06 & 0.22 & 2.09 & 0.10 \\
\hline 11 & 155 & 128 & 13.23 & 3.25 & 0.25 & 2.11 & 0.11 \\
\hline 12 & 72 & 51 & 13.89 & 3.42 & 0.25 & 2.04 & 0.38 \\
\hline 13 & 112 & 163 & 13.89 & 3.21 & 0.23 & 2.03 & 0.24 \\
\hline 14 & 158 & 115 & 13.49 & 2.35 & 0.17 & 2.31 & 0.09 \\
\hline 15 & 160 & 134 & 13.33 & 2.26 & 0.17 & 2.25 & 0.07 \\
\hline 16 & 56 & 93 & 13.58 & 3.69 & 0.27 & 2.19 & 0.36 \\
\hline 17 & 106 & 141 & 12.58 & 3.13 & 0.25 & 1.81 & 0.32 \\
\hline 18 & 110 & 141 & 12.79 & 2.92 & 0.23 & 1.95 & 0.29 \\
\hline 19 & 154 & 132 & 14.22 & 3.15 & 0.22 & 2.19 & 0.07 \\
\hline 20 & 66 & 109 & 15.46 & 4.12 & 0.27 & 2.27 & 0.39 \\
\hline 21 & 66 & 99 & 14.33 & 3.60 & 0.25 & 2.13 & 0.42 \\
\hline 22 & 98 & 106 & 13.75 & 2.86 & 0.21 & 2.10 & 0.32 \\
\hline Mean & 110 & 115 & 13.64 & 3.02 & 0.22 & 2.06 & 0.25 \\
\hline Range & $56-160$ & $51-158$ & $10.16-15.46$ & $1.31-4.12$ & $0.13-0.27$ & $1.74-2.31$ & $0.07-0.42$ \\
\hline $\mathrm{SD}$ & 33 & 26 & 1.22 & 0.62 & 0.04 & 0.15 & 0.11 \\
\hline
\end{tabular}

$\mathrm{CoA}=$ Cochlear area $\mathrm{MoA}=$ modiolar area

R2 was a strongly suggestive parameter (area under the ROC curve $=0.94$ ), with a sensitivity and specificity of $86.4 \%$ using a threshold value of $72^{\circ}$ (i.e. an R2 angle of at least $72^{\circ}$ was associated with scala communis). AB was less diagnostic of the scala communis defect (area under the ROC curve $=0.81$ ), with a sensitivity of $86.4 \%$ and a specificity of $59.1 \%$ using a threshold value of $0.36 \mathrm{~mm}$ (i.e. an $\mathrm{AB}$ distance of less than $0.36 \mathrm{~mm}$ ) (fig. 4).

\section{Discussion}

The incidence of scala communis in our temporal bone collection was $2.4 \%$. Scala communis can occur in cochleae with a normal number of turns and normal size. Also, it can occur as an isolated anomaly, as was the case in 17 of our 22 ears.

\section{Effect on Hearing}

The process of auditory transduction within the cochlea is initiated by sound-induced motion of the stapes in the oval window, which results in a pressure difference between the scala vestibuli and scala tympani [Wever and Lawrence, 1950; Voss et al., 1996]. One would expect scala communis to interfere with the creation of such a pressure difference and thereby affect the normal motion of the basilar membrane. Many of our cases had hearing loss, but other pathologies (e.g. atrophy of the organ of Corti from labyrinthitis, etc.) confounded a possible link between hearing loss and scala communis. Interestingly, 4 cases with scala communis had normal hearing as assessed by audiometry. Audiograms for frequencies of $250-8000 \mathrm{~Hz}$ in all 4 ears showed air conduction thresholds at $20 \mathrm{~dB}$ or better. Of these 4 cases, 3 had IS3 defects, and 1 had a combined IS2 and IS3 defect. All 4 ears had normal lengths of the cochlear duct. Spiral ganglion re- 
Control ears

\begin{tabular}{|c|c|c|c|c|c|c|c|}
\hline $\begin{array}{l}\text { Ear } \\
\text { No. }\end{array}$ & $\begin{array}{l}\text { Angle R2 } \\
\text { degrees }\end{array}$ & $\begin{array}{l}\text { Angle R3 } \\
\text { degrees }\end{array}$ & $\begin{array}{l}\mathrm{CoA} \\
\mathrm{mm}^{2}\end{array}$ & $\begin{array}{l}\mathrm{MoA} \\
\mathrm{mm}^{2}\end{array}$ & MoA/CoA & $\begin{array}{l}\mathrm{AC} \\
\mathrm{mm}\end{array}$ & $\begin{array}{l}\mathrm{AB} \\
\mathrm{mm}\end{array}$ \\
\hline 1 & 74 & 51 & 12.88 & 3.73 & 0.29 & 1.94 & 0.30 \\
\hline 2 & 52 & 65 & 15.35 & 4.36 & 0.28 & 2.09 & 0.37 \\
\hline 3 & 57 & 48 & 13.30 & 3.58 & 0.27 & 1.79 & 0.40 \\
\hline 4 & 63 & 42 & 18.28 & 5.38 & 0.29 & 2.46 & 0.42 \\
\hline 5 & 54 & 46 & 15.83 & 4.42 & 0.28 & 2.13 & 0.40 \\
\hline 6 & 40 & 52 & 13.38 & 3.69 & 0.28 & 1.96 & 0.39 \\
\hline 7 & 55 & 51 & 13.55 & 3.47 & 0.26 & 1.98 & 0.41 \\
\hline 8 & 61 & 58 & 14.69 & 4.37 & 0.30 & 2.16 & 0.39 \\
\hline 9 & 46 & 60 & 13.87 & 3.71 & 0.27 & 2.06 & 0.42 \\
\hline 10 & 97 & 88 & 16.79 & 4.00 & 0.24 & 2.41 & 0.28 \\
\hline 11 & 66 & 53 & 13.84 & 4.00 & 0.29 & 1.83 & 0.34 \\
\hline 12 & 40 & 54 & 13.77 & 3.76 & 0.27 & 1.88 & 0.48 \\
\hline 13 & 52 & 58 & 11.74 & 3.11 & 0.26 & 1.95 & 0.32 \\
\hline 14 & 66 & 51 & 15.48 & 4.36 & 0.28 & 2.17 & 0.27 \\
\hline 15 & 47 & 65 & 15.03 & 4.41 & 0.29 & 2.10 & 0.46 \\
\hline 16 & 69 & 56 & 12.62 & 2.98 & 0.24 & 2.03 & 0.20 \\
\hline 17 & 37 & 55 & 16.20 & 4.95 & 0.31 & 2.35 & 0.49 \\
\hline 18 & 51 & 48 & 13.48 & 3.91 & 0.29 & 1.87 & 0.31 \\
\hline 19 & 62 & 53 & 15.10 & 3.78 & 0.25 & 2.05 & 0.46 \\
\hline 20 & 53 & 41 & 13.46 & 3.17 & 0.24 & 1.99 & 0.47 \\
\hline 21 & 70 & 70 & 14.71 & 3.68 & 0.25 & 2.01 & 0.22 \\
\hline 22 & 78 & 76 & 13.64 & 3.61 & 0.26 & 2.05 & 0.32 \\
\hline Mean & 59 & 56 & 14.41 & 3.93 & 0.27 & 2.06 & 0.37 \\
\hline Range & $37-97$ & $41-88$ & $11.74-18.28$ & $2.98-5.38$ & $0.24-0.31$ & $1.79-2.46$ & $0.20-0.49$ \\
\hline SD & 14 & 11 & 1.51 & 0.58 & 0.02 & 0.17 & 0.08 \\
\hline
\end{tabular}

construction was feasible in 3 of the 4 cases. The length of Rosenthal's canal and the spiral ganglion counts in the 3 cases were within the expected range of age-matched counts. We do not have an explanation for the lack of hearing loss in these 4 cases; it is an issue that needs research.

\section{Radiological Implications}

Scala communis is analogous to the anomaly that radiologists described as incomplete partition or undersegmentation of the cochlea [Jackler et al., 1987; Jardin and Vignaud, 1988; Phelps, 1990; Sennaroglu and Saatçi, 2002, 2004; Romo et al., 2003]. Imaging techniques at the present time do not permit direct visualization of the IS in a consistent and reliable manner. Hence, the radiological diagnosis of this anomaly may be made on the basis of an abnormality in the outline of the bony turns of the cochlea ('segmentation' or 'partition') (fig. 5). Of note, a radiological diagnosis of undersegmentation or incomplete parti- tion is usually made in cases that have other inner ear anomalies such as an enlarged vestibular aqueduct, Mondini deformity and others. It may be that a large vestibular aqueduct brings the undersegmentation anomaly to the attention of the radiologist, especially when the anomaly is mild. Our study clearly demonstrates that scala communis can occur by itself without other inner ear anomalies. Hence, radiologists should be able to make a diagnosis of isolated undersegmentation. Our histological data show that flattening of the interscalar ridge between the upper basal and upper middle turns is invariably associated with scala communis. When appreciated on a highresolution CT scan, flattening of the interscalar ridge can be used as a diagnostic sign of scala communis. Our study also indicates that the radiological diagnosis could possibly be improved by using angle $\mathrm{R} 2$ and distance $A B$ as quantitative parameters. However, this may be a problem with the current resolution of CT scans. 


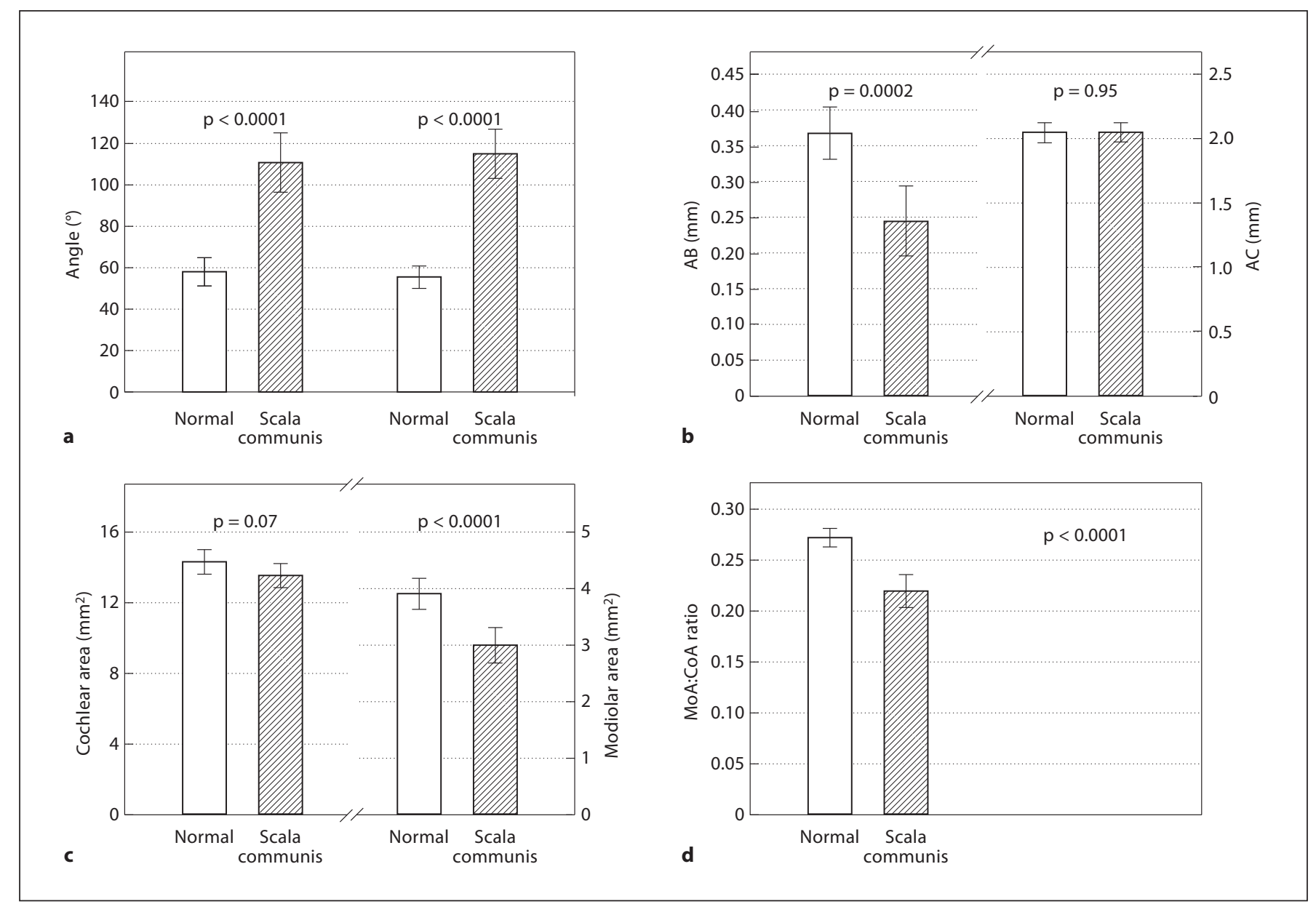

Fig. 3. Histograms. Columns: means. Whiskers: 95\% CI. a Angles R2 (left) and R3 (right). b Distances AB (left) and AC (right). c Cochlear (left) and modiolar area (right). $\mathbf{d}$ Ratio of modiolar to cochlear area.

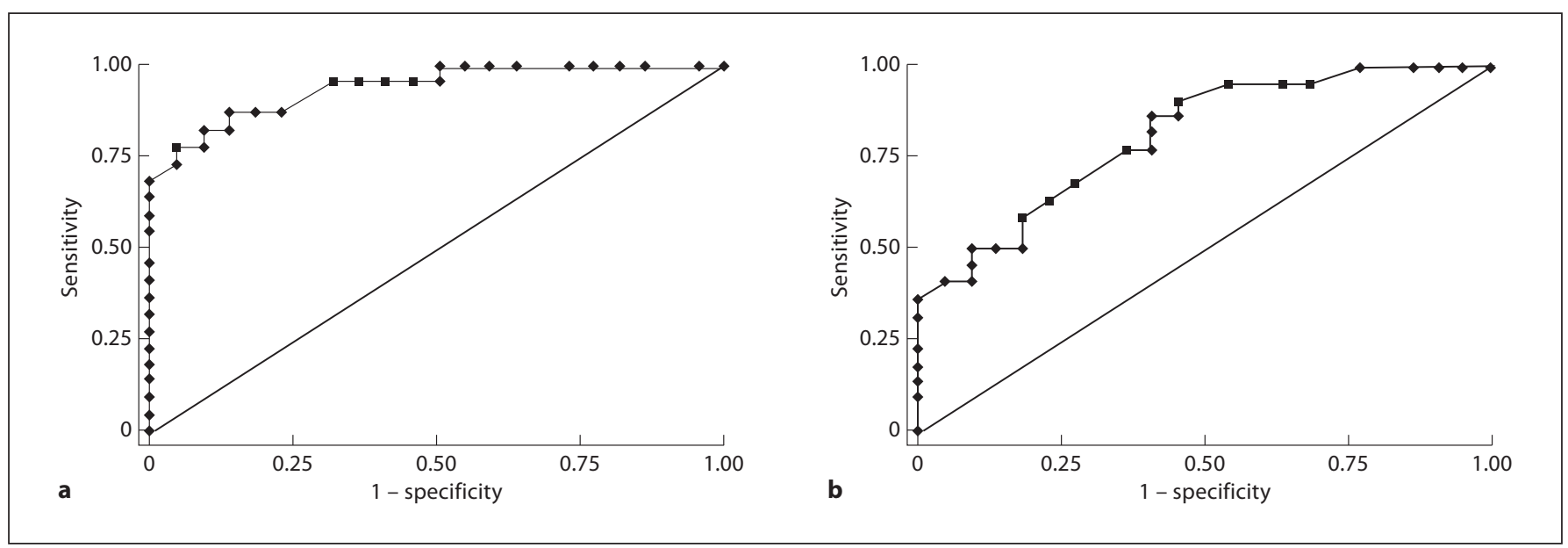

Fig. 4. ROC curves for angle $\mathrm{R} 2$ (a) and distance $\mathrm{AB}$ (b) showing the sensitivity and specificity of using each parameter as a diagnostic test. $\mathbf{a}$ Area under the ROC curve $=0.94$. $\mathbf{b}$ Area under the ROC curve $=0.81$. 
Fig. 5. High-resolution CT scans of normal right cochlea (a) and right cochlea with 'incomplete partition' or 'undersegmentation' anomaly (b). Arrows: R2; appears flattened in $\mathbf{b}$.
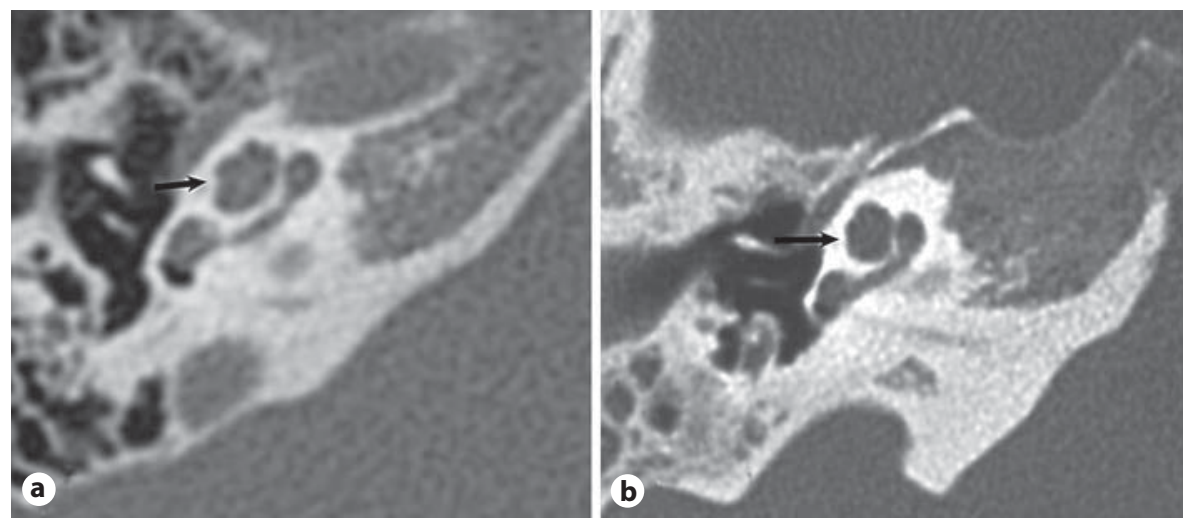

Table 4. Reconstruction of the cochlear duct and spiral ganglion in ears with scala communis

\begin{tabular}{|c|c|c|c|c|}
\hline \multirow{2}{*}{$\begin{array}{l}\text { Ear/side } \\
\text { No./- }\end{array}$} & \multirow{2}{*}{$\begin{array}{l}\text { Cochlear duct } \\
\text { length, mm }\end{array}$} & \multicolumn{2}{|c|}{ Spiral ganglion cell count } & \multirow{2}{*}{$\begin{array}{l}\text { Rosenthal canal } \\
\text { length, } \mathrm{mm}\end{array}$} \\
\hline & & total & percent of control $^{1}$ & \\
\hline $1 / \mathrm{L}$ & 24.9 & 27711 & 78 & cells in IAC \\
\hline $2 / \mathrm{L}$ & 23.5 & 441 & 1 & 1.4 \\
\hline $3 / \mathrm{L}$ & 28.0 & 28593 & 86 & 14.2 \\
\hline $4 / \mathrm{R}^{2}$ & 35.3 & 22293 & 67 & 14.2 \\
\hline $5 / \mathrm{L}$ & 36.2 & \multicolumn{3}{|c|}{ craniopharyngioma into IAC } \\
\hline $6 / R^{2}$ & 31.9 & 32877 & 113 & 13.8 \\
\hline $7 / \mathrm{R}^{2}$ & 34.2 & \multicolumn{3}{|l|}{ artifact } \\
\hline $8 / \mathrm{L}^{2}$ & 31.8 & 21753 & 80 & 14.7 \\
\hline 9/R & 30.5 & 25974 & 104 & 14.5 \\
\hline $10 / \mathrm{R}$ & 28.1 & \multicolumn{3}{|c|}{ measles labyrinthitis } \\
\hline $11 / \mathrm{L}$ & 27.4 & \multicolumn{3}{|c|}{ measles labyrinthitis } \\
\hline $12 / \mathrm{R}$ & 31.7 & 32985 & 132 & 16.5 \\
\hline $13 / \mathrm{L}$ & 27.5 & 10116 & 44 & 13.2 \\
\hline $14 / \mathrm{R}$ & 29.5 & 14445 & 63 & 13.6 \\
\hline $15 / \mathrm{L}$ & 27.3 & 18486 & 81 & 14.7 \\
\hline $16 / \mathrm{R}$ & 30.6 & \multicolumn{3}{|c|}{ Usher's syndrome } \\
\hline $17 / \mathrm{R}$ & 29.8 & 19521 & 85 & 12.0 \\
\hline $18 / \mathrm{L}$ & 30.8 & \multicolumn{3}{|c|}{ osteoradionecrosis } \\
\hline $19 / \mathrm{R}$ & 29.3 & 19332 & 93 & 13.0 \\
\hline $20 / \mathrm{R}$ & 29.9 & 17622 & 85 & 13.9 \\
\hline $21 / \mathrm{L}$ & 30.3 & 17073 & 82 & 14.6 \\
\hline $22 / \mathrm{L}$ & 26.0 & \multicolumn{3}{|c|}{ DFNA9 } \\
\hline $\begin{array}{l}\mathrm{IAC}= \\
{ }^{1} \text { Perc } \\
{ }^{2} \mathrm{Doc}\end{array}$ & $\begin{array}{l}\text { ernal auditory } \\
\text { ge of age-matc } \\
\text { ented normal he }\end{array}$ & $\begin{array}{l}\text { al. } \\
\text { contro } \\
\text { ng. }\end{array}$ & & \\
\hline
\end{tabular}

\section{Embryology}

The development of the scalae, IS and modiolus has been described in detail by Streeter [1906, 1917a, b, 1918], and Bast and Anson [1949]. Briefly, the otic duct (future scala media) starts to develop as a small bud from the ectodermal otic vesicle at about 4-5 weeks of gestational age. This bud elongates and curls to form 2.5 turns by $8-10$ weeks. The scala vestibuli, scala tympani, modiolus and otic capsule develop from mesenchyme that surrounds the ectodermal otic duct, with a slight delay compared to the otic labyrinth. The scala tympani and scala vestibuli develop by a system of cavitation and excavation of the mesenchyme surrounding the otic duct. This cavitation occurs in response to the presence 
Fig. 6. Fetuses at 8 weeks (a), 12 weeks (b) and 16 weeks (c) of gestational age showing different stages of maturation of the modiolus and IS. d Newborn, shown for comparison.

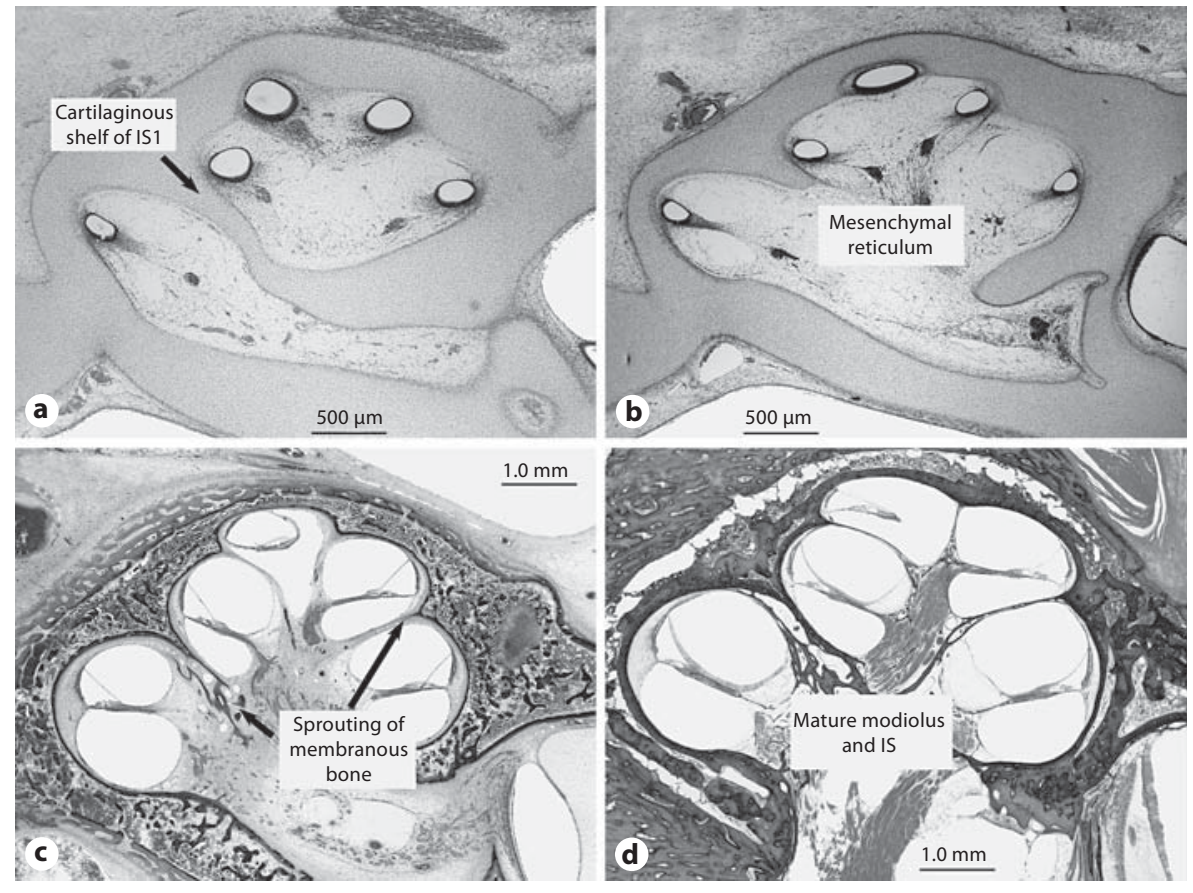

of the ectodermal component, i.e. the otic duct. The modiolus forms by membranous ossification. As the scalae form at the expense of the mesenchyme, the scala tympani of one turn approaches the scala vestibuli of the next. The IS forms where the respective scalae abut. The IS separating the lower basal turn from the lower middle turn (IS1) is partly formed by ossification of cartilage. The more apical portions of the septum (IS2 and IS3) form by membranous ossification without a cartilage precursor. Figure 6 shows the histological appearance of fetal cochleae at 8,12 and 16 weeks of gestational age, showing different stages of maturation of the modiolus and IS.

These embryological observations have relevance to the scala communis anomaly. The separate origin of the proximal IS (endochondral ossification) compared to the apical septum (intramembranous bone) is noteworthy in light of our finding that the vast majority of defects in our study were in the apical septum (IS2 and IS3). Possible mechanisms for the majority of cases in our study include a defect in the formation of membranous bone, or an overly aggressive resorption of mesenchyme. These mechanisms can also explain hypoplasia of the modiolus, which was often seen to accompany scala communis. The baseto-apex formation of the IS also helps to explain our observation that a defect of IS2 was followed by a defect of IS3, but not vice versa.
It is noteworthy that all cases of scala communis in the present study had a scala media and organ of Corti that consisted of all 3 turns (basal, middle and apical). Therefore, this anomaly cannot be explained on the basis of arrested maturation of the otic vesicle, as hypothesized by Jackler et al. [1987]. We believe that the anomaly has a mesenchymal origin, as described above.

\section{Conclusions}

Scala communis occurred as an isolated anomaly or in association with other labyrinthine defects. Scala communis occurred most often between the middle and apical turns of the cochlea. Flattening of the interscalar ridge has the potential to improve its diagnosis in patients using CT scanning. The anomaly appears to result from a mesodermal problem such as excessive resorption of mesenchyme during the formation of the scalae, an error in the formation of bone, or both.

\section{Acknowledgments}

The study was supported by NIDCD (National Institute on Deafness and Other Communication Disorders) grant U24DC008559. We also thank Mr. Axel Eliasen and Mr. Lakshmi Mittal for their support. 


\section{References}

-Alexander G: Zur Pathologie und pathologischen Anatomie der kongenitalen Taubheit. Arch Ohrenheilkd 1904;61:183-219.

Altman F: Malformations, anomalies, and vestigial structures of the inner ear. Arch Otolaryngol 1953;57:591-602.

Bast TH, Anson BJ: The Temporal Bone and the Ear. Springfield, CC Thomas, 1949.

Guild S: A case of bilateral scala communis cochleae uncomplicated by other defects: an embryological interpretation of this and associated anomalies. Anat Rec 1929;42:19.

- Guild SR, Crowe SJ, Bunch CC, Polvogt LM: Correlations of differences in the density of innervations of the organ of Corti with differences in the acuity of hearing, including evidence as to the location in the human cochlea of the receptors for certain tones. Acta Otolaryngol 1931;15:269-308.

Jackler RK, Luxford WM, House WF: Congenital malformations of the inner ear: a classification based on embryogenesis. Laryngoscope 1987;97(suppl 40):2-14.

Jardin C, Vignaud J: Malformations de l'oreille: bilan radiologique. Encyclopédie médicochirurgicale 1988;20047-A:30-9.

Mondini C: Anatomica hati sectio. De Bononiensi Scientarum et Artium Instituto atque Academia Commentarii. Bononiae 1791;7: 28, 419.

Nager FR: Beiträge zur Histologie der erworbenen Taubstummheit. Z Ohrenheilkd 1907; 54:217-244.
Otte J, Schuknecht HF, Kerr AG: Ganglion cell populations in normal and pathological human cochleae: implications for cochlear implantation. Laryngoscope 1978;88:12311246.

Paparella MM: Mondini Deafness: a review of histopathology. Ann Otol Rhinol Laryngol 1980;89(suppl 67):1-10.

Phelps PD: Mondini and pseudo-Mondini. Clin Otolaryngol 1990;15:99-101.

Romo LV, Casselman JW, Robson CD: Temporal bone: congenital anomalies; in Som PM, Curtin HD (eds): Head and Neck Imaging. St Louis, Mosby, 2003, pp 1109-1171.

Schuknecht HF: Techniques for study of cochlear function and pathology in experimental animals: development of the anatomical frequency scale for the cat. Arch Otolaryngol 1953;58:377-397.

Schuknecht HF: Pathology of the Ear, ed 1. Cambridge, Harvard University Press, 1974.

Schuknecht HF: Mondini's dysplasia: a clinical and pathological study. Ann Otol Rhinol Laryngol 1980;89(suppl 65):3-23.

Schuknecht HF: Pathology of the Ear, ed 2. Philadelphia, Lea and Gebieger, 1993.

-Sennaroglu L, Saatçi I: A new classification for cochleovestibular malformations. Laryngoscope 2002;112:2230-2241.
Sennaroglu L, Saatçi I: Unpartitioned versus incompletely partitioned cochleae: radiologic differentiation. Otol Neurotol 2004;25:520529.

Streeter GL: On the development of the membranous labyrinth and the acoustic and facial nerves in the human embryo. Am J Anat 1906;6:139.

Streeter GL: Development of the scala tympani, scala vestibuli, and periotic cistern in human embryos. Am J Anat 1917a;21:299-320.

Streeter GL: The factors involved in the excavation of the cavities in the cartilaginous capsule of the ear in the human embryo. Am J Anat 1917b;22:1-25.

Streeter GL: The histogenesis and growth of the otic capsule and its contained periotic tissuespaces in the human embryo. Contrib Embryol Carnegie Inst Wash 1918;7:5-54.

Voss SE, Rosowski JJ, Peake WT: Is the pressure difference between the oval and round windows the effective acoustic stimulus for the cochlea? J Acoust Soc Am 1996;100:16021616.

Wever EG, Lawrence M: The acoustic pathways to the cochlea. J Acoust Soc Am 1950;22: 460-467.

Zheng Y, Schachern PA, Cureoglu S, Mutlu C, Dijalilian H, Paparella MM: The shortened cochlea: its classification and histopathological features. Int J Ped Otorhinolaryngol 2002;63:29-39. 